\title{
Perbandingan metode latihan dan power otot lengan terhadap hasil tolak peluru
}

\author{
Alit Sundari *, Sukadiyanto \\ Program Studi Ilmu Keolahragaan, Program Pascasarjana, Universitas Negeri Yogyakarta \\ Jalan Colombo, No. 1, Karangmalang, Yogyakarta 55281, Indonesia \\ *Corresponding Author. Email: alit_sundari@yahoo.com
}

\begin{abstract}
Abstrak
Penelitian ini bertujuan untuk mengetahui: (1) Perbedaan pengaruh metode latihan dengan menggunakan drill dan bermain terhadap peningkatan hasil tolak peluru. (2) Perbedaan pengaruh antara siswa yang memiliki power tinggi dan siswa yang memiliki power rendah hasil tolak peluru. (3) Interaksi antara metode latihan dan power otot lengan terhadap hasil tolak peluru. Penelitian menggunakan metode eksperimen rancangan $2 \times 2$. Populasi penelitian siswa putra kelas VIII SMP Piri Ngaglik Sleman usia 14-15 tahun berjumlah 72 siswa. Sampel penelitian 40 siswa yang diambil dengan teknik purposive sampling. Data penelitian diperoleh melalui tes dan pengukuran terhadap power otot lengan dan hasil tolak peluru. Teknik analisis data yang digunakan adalah analisis varian (ANAVA) dua jalur pada taraf signifikan $\alpha=0,05$. Hasil penelitian menunjukkan bahwa: (1) ada perbedaan pengaruh yang signifikan antara metode drill dan bermain terhadap hasil tolak peluru, dibuktikan dengan nilai $\mathrm{p}=0,032<0,05$. Metode drill memiliki pengaruh yang lebih besar daripada metode bermain, dibuktikan dengan nilai mean difffrence (selisih rata-rata) adalah 0,637. (2) Ada perbedaan pengaruh yang signifikan antara siswa yang memiliki power lengan tinggi dan siswa yang memiliki power lengan rendah terhadap hasil tolak peluru, dibutikan dengan nilai $p=0,00<0.05$ Power lengan tinggi memiliki pengaruh yang lebih besar daripada power lengan rendah, dibuktikan dengan nilai mean difffrence (selisih rata-rata) adalah 2,181. (3) Tidak ada interaksi antara metode latihan dan power lengan terhadap hasil tolak peluru dibuktikan dengan nilai $p=0,865>0,05$.

Kata Kunci: Tolak peluru; metode latihan; power otot lengan; hasil tolak peluru
\end{abstract}

\section{The comparison between the exercise's methods and arm's muscle power on the result of shot put}

\begin{abstract}
This research aims to determine: (1) effect's differences of the exercise methods by using drill and play on the result's improvement of shot put. (2) effect's differences between students who have high power and students who have low one on the result of shot put. (3) Interaction between the exercise methods and arm's muscle power on the result of shot put. This research used experiment method of 2 $x 2$ design. The population covered 72 male students of $8^{\text {th }}$ grade of Piri Junior High School aged 1415 years old in Ngaglik, Sleman regency. The sample of this research was 40 students taken by using purposive sampling technique. The data of the research were taken through the test and measurement on arm's muscle power and result of shot put. Data's analysis technique used in this research was two tracks of varian analysis (called ANAVA) on significant rate $\alpha=0.05$. The result of this research shows that: (1) there is a significant effect's difference between drilling method and playing method on the result of shot put which is proved by value of $p=0.032<0.05$. Drilling method has greater effect than playing method which is proved by the value of mean difference (difference in average) is 0.637. (2) there is a significant effect's difference between students who have high arm's power and students who have low one on the result of shot put, which is proved by value of $p=0.00<0.05$. The high arm's power has greater effect than the low one which is proved by the value of mean difference (difference in average) is 2.181. (3) There is no interaction between the exercise methods and arm's muscle power on the result of shot put which is proved by value of $p=0.865>0.05$.
\end{abstract}

Keywords: Shot put; exercise's methods; arm's muscle power; result of shot put 


\section{PENDAHULUAN}

The shot put is usually considered a pushing event (Derse, at.al, 2008, p.399). Tolak peluru masuk ke dalam nomor lempar namun pada pelaksanaan melepaskan peluru gerakan yang digunakan bukan gerakan melempar melainkan menolak. Menurut Widya (2004, p.152) tolakan adalah suatu gerakan menyalurkan tenaga pada suatu benda yang menghasilkan kecepatan dan memiliki daya dorong yang kuat ke depan, perbedaan dengan melempar terletak pada pelepasan benda, pada saat menolak pergelangan tidak bergerak dan tenaga diperoleh dari gerakan meluruskan siku. Menurut Purnomo (2007, p. 116) tolak peluru merupakan bagian dari nomor lempar, yang mempunyai karakteristik sendiri yaitu peluru tidak dilempar tetapi ditolak atau didorong dari bahu dengan satu tangan Tujuan menolak atau mendorong peluru adalah untuk menghasilkan tolakan yang sejauhjauhnya. Hasil tolakan yang jauh pada peluru diperlukan beberapa aspek pendukung yaitu aspek teknik, fisik dan juga mental.

The two most common techniques of shot putting are the glide and the spin. The glide technique is an easier technique for high school athletes to learn, but the spin technique may have more advantages for certain athletes (Derse, et al, 2008, p. 404). Menurut Purnomo \& Dapan (2011, p.134) dalam tolak peluru ada dua teknik yang berbeda pada saat ini sangat dominan dipakai oleh para atlet, yaitu gaya meluncur (glide) dan gaya berputar (rotasi). Teknik tolak peluru gaya meluncur (glide style) dianggap teknik yang lebih mudah dan cocok untuk pelempar pemula. Teknik yang sempurna dalam tolak peluru dapat menciptakan gerakan yang efektif dan efisien. Teknik yang sempurna dapat dicapai melalui belajar dan berlatih. Dengan belajar dan berlatih seorang atlet akan lebih mahir dan terampil dalam melakukan tolak peluru. Selain penguasaan teknik yang baik, faktor penting yang menentukan jauhnya tolak peluru adalah faktor fisik.

Menurut Purnomo \& Dapan (2011, p. 133) aspek fisik yang berkaitan dengan tolak peluru adalah kekuatan, kekuatan maksimal, power, kekuatan lempar dan didukung oleh kecepatan, kecepatan berakselerasi serta koordinasi, adaptability dan kemampuan berirama. Menurut Purnomo \& Dapan (2011, p. 133) faktor penting yang menentukan jauhnya hasil tolakan adalah gerak percepatan (akselerasi) terhadap beban dari peluru dicapai oleh daya kekuatan pelurusan otot-otot tungkai, torso, dan lengan. Hal ini membutuhkan kekuatan terutama kekuatan maksimal, power dan kekuatan saat menolak.

Beberapa karakteristik dari tolak peluru gaya meluncur, juga menimbulkan masalah bagi pelempar untuk menghasilkan tolakkan yang jauh. Salah satu masalahnya adalah kekuatan dan kecepatan. Gerakan yang mengkombinasikan kekuatan dan kecepatan disebut dengan power. Power is a product of the strength of the muscle and the speed of the contraction (SSC) (Gordon, 2009, p.168). Strength and speed result in power, or the rate of which you can generate force. This is usually fast, with explosiveness, such as batting or jumping (Bompa, 2000, p.94). Power (kekuatan explosive) yaitu kemampuan otot atau sekolompok otot untuk mengatasi beban dengan gerakan yang cepat, misalnya melompat, melempar dan memukul (Irianto, 2002, p.67). Menurut Komi (2003, p.3) power is the rate at which work is performed or the rate of the transformation of metabolic potential energy to work and/or heat.

Dapat disimpulkan bahwa power adalah hasil gabungan antara kekuatan dan kecepatan. Power merupakan salah satu aspek yang harus mendapat perhatian dalam tolak peluru, di mana dalam penerapan teknik tolak peluru gaya meluncur (glide style) harus dilakukan dengan gerakan yang kuat dan cepat. Gerakan yang dilakukan dengan kuat dan cepat bertujuan untuk memperkecil adanya tahanan hambatan yang akan mempengaruhi hasil tolak peluru. Power lengan setiap individu berbeda ada yang memiliki power lengan tinggi dan ada juga yang memiliki power lengan rendah, tingkat kemampuan power yang dimiliki seorang pelempar juga akan mempengaruhi hasil tolak peluru.

Hasil adalah pendapatan (perolehan) atau akibat dari hasil usaha (Qodratillah, dkk, 2008, p.486). Shot put an athletics event in which contestants compete to throw a heavy metal ball as far as possible (Anonim, 2006, p.189). Artinya, tolak peluru adalah sebuah event atletik di mana kontestan bersaing untuk menolak peluru sejauh mungkin.

Hasil tolak peluru adalah perolehan yang dicapai dalam menolak peluru. Adapun akibat dari tolak peluru adalah jarak jatuhnya peluru yang ditolak dan diukur dalam satuan centi meter. Hasil tolak peluru dapat maksimal karena adanya bimbingan, pengajaran dan latihan. Pembelajaran tolak peluru, pencapaian tujuan tolak peluru dapat dicapai dengan menerapkan metode latihan. Metode 
menurut J.R. David (Majid, 2013, p.21) ialah 'a way in achieving something' (cara untuk mencapai sesuatu). Metode adalah cara yang dapat digunakan untuk melaksanakan strategi. Metode adalah $a$ way in achieving something (Sanjaya, 2009, p.127). Metode latihan adalah cara yang dilakukan untuk meningkatkan prestasi olahraga.

Pada latihan tolak peluru, pelatih (guru) seharusnya menerapkan beberapa metode latihan secara bervariasi. Namun kenyataan di lapangan peneliti melakukan beberapa observasi, guru hanya menggunakan salah satu metode latihan saja. Salah satu metode yang digunakan adalah metode drill.

Drill secara denotative merupakan tindakan untuk meningkatkan keterampilan dan kemahiran (Majid, 2013, p.214). Roestiyah (2001, p.125) teknik latihan atau drill adalah suatu teknik yang dapat diartikan sebagai suatu cara mengajar dimana siswa melaksanakan kegitan-kegitan latihan, agar siswa memiliki ketangkasan atau keterampilan yang lebih tinggi dari apa yang dipelajari. Menurut Hardini \& Puspitasari (2012, p.39) \& Majid (2013, p.214) dalam melaksanakan metode drill ada beberapa yang harus diperhatikan; siswa harus diberi pengertian yang mendalam sebelum diadakan latihan tertentu, latihan pertama kali bersifat diagnosis, mula-mula kurang berhasil lalu diadakan perbaikkan untuk kemudian agar lebih sempurna. Latihan tidak perlu lama asal sering dilaksanakan. Harus disesuaikan dengan taraf kemampuan siswa, latihan hendaknya mendahulukan hal-hal yang esensial dan berguna.

Ada beberapa masalah yang menjadi kendala mengapa guru menggunakan metode drill. Pertama, fasilitas tolak peluru yang kurang memadai, jumlah peluru yang terbatas tidak sebanding dengan jumlah siswa yang banyak. Kedua, faktor keselamatan dalam latihan. Karena keterbatasan alat dan jumlah siswa yang banyak serta tolak peluru yang mengandung resiko yang cukup tinggi, menjadi alasan bagi guru untuk menggunakan metode latihan drill. Penggunaan metode drill memudahkan guru untuk mengontrol jalannya latihan, karena sesuai dengan instruksi guru.

Berdasarkan hasil observasi, meskipun kebanyakan guru menggunakan metode drill dalam latihan tolak peluru, namun ada beberapa guru yang menggunakan metode bermain. Bermain digunakan sebagai media untuk meningkatkan keterampilan dan kemampuan tertentu (Tedjasaputra, 2001, p.2). Bermain adalah sarana melatih keterampilan yang dibutuhkan untuk menjadi individu yang kompeten, bermain adalah pengalaman multidimensi yang melibatkan indera dan mengugah kecerdasan, bermain merupakan kesadaran untuk belajar tentang bagaimana seharusnya belajar (Sujiono \& Sujiono, 2010, p.35).

Alasan menggunakan metode bermain adalah belajar sambil bermain. Melalui bermain siswa dapat melakukan gerakan dengan perasaan senang, menantang dan dapat bergerak secara aktif. Dengan demikian siswa akan bersungguh-sungguh melakukan aktivitas latihan sehingga akan berpengaruh terhadap hasil tolak peluru. Agar aktivitas metode bermain dapat berjalan dengan baik dan berpengaruh terhadap hasil tolak peluru, maka aktivitas latihan dengan bermain harus berkaitan langsung dengan dengan aspek yang terkandung dalam tolak peluru dan tidak dangkal.

Untuk mengatasi permasalahan tersebut, baik pelatih (guru) mempunyai peranan yang penting dalam menentukan metode latihan yang digunakan. Guru harusnya selalu mengerti dan memahami karakterisitik dan kebutuhan siswa, sehingga aktivitas latihan memiliki variasi dan tidak menoton. Pada tolak peluru dapat menggunakan metode latihan dengan metode drill dan metode bermain yang telah dimodifikasi.

Alasan peneliti memilih metode drill dan metode latihan bermain adalah: (1) Metode drill adalah metode yang dilakukan secara bertahap atau step-by-step, adanya pengulangan dan dilakukan dengan intruksi pelatih sehingga memudahkan siswa untuk latihan tolak peluru. (2) Metode latihan dengan bermain yang memiliki keuntungan yaitu bermain sambil belajar, sehingga dengan diciptakan suasana bermain yang menyenangkan diharapkan siswa tidak terasa sedang belajar tetapi bermain. Dengan demikian siswa dapat belajar sambil bermain tanpa mengesampingkan tujuan latihan yang telah ditetapkan dan siswa menjadi tertarik untuk mempelajari tolak peluru.

Metode drill dan metode latihan bermain memiliki perbedaan, untuk itu dalam penerapannya di dalam latihan tolak peluru, harus memperhatikan faktor-faktor lain yang berkaitan dengan tolak peluru salah satunya adalah power lengan. Untuk itu perlu adanya penelitian yang berhubungan penerapan metode latihan drill dan metode latihan bermain serta power lengan dengan tujuan mengetahui perbedaan pengaruh kedua metode dan power lengan terhadap hasil tolak peluru. 


\section{JORPRES (Jurnal Olahraga Prestasi), 15 (1), 2019 - 50}

Pasha Erik Juntara, Hari Amirullah Rachman

\section{METODE}

Jenis penelitian ini adalah eksperimen dengan desain factorial $2 \times 2$. Penelitian ini adalah penelitian ekperimen menggunakan dua kelompok yang memperoleh perlakuan (treatment) yang berbeda berupa metode latihan, yaitu metode latihan drill dan metode latihan bermain. Rancangan penelitian seperti pada tabel 1 .

Tabel 1. Kerangka Desain Penelitian

\begin{tabular}{lcc}
\hline & \multicolumn{2}{c}{ Metode Latihan } \\
\cline { 2 - 3 } Variabel Atribut & $\operatorname{Drill}\left(A_{1}\right)$ & Bermain $\left(A_{2}\right)$ \\
\hline Power Otot Lengan Tinggi $\left(B_{1}\right)$ & $A_{1} B_{1}$ & $A_{2} B_{1}$ \\
Power Otot Lengan Rendah $\left(B_{2}\right)$ & $A_{1} B_{2}$ & $A_{2} B_{2}$ \\
\hline Kenilatif &
\end{tabular}

Keterangan:

$A_{1} B_{1}$ : kelompok siswa yang mempunyai power tinggi dan diberikan latihan dengan metode drill.

$A_{2} B_{1}$ : kelompok siswa yang mempunyai power tinggi dan diberikan latihan dengan metode bermain.

$A_{1} B_{2}$ : kelompok siswa yang mempunyai power rendah dan diberi latihan dengan metode $d r i l l$.

$A_{2} B_{2}$ : kelompok yang memiliki power rendah dan diberikan latihan dengan metode bermain.

Penelitian ini dilaksanakan di SMP Piri Sinduarjo Ngaglik Sleman Yogyakarta. Waktu penelitian dilaksanakan tanggal 3 April 2014 sampai 24 Mei 2014. Perlakuan penelitian dilakukan selama 16 kali pertemuan dengan frekuensi latihan tiga kali dalam seminggu. Maksudnya agar tubuh beradaptasi dengan beban latihan yang diterima (Bompa \& Haff, 2009, p.207).

Populasi dalam penelitian ini berjumlah 72 siswa putra kelas VIII SMP PIRI Sinduarjo Ngaglik Sleman Yogyakarta, yang diambil sebagai sampel 40 siswa dengan cara porposive sampling. Untuk membagi kelompok dengan cara mengadakan tes power otot lengan yang merupakan variabel atribut dalam penelitian ini.

Tes tersebut untuk menentukan kelompok yang memiliki power lengan tinggi dan rendah. Tahap selanjutnya adalah merengking hasil skor power lengan yang diperoleh setiap anak pada setiap kelompok perlakuan.

Untuk menentukan power tinggi dan rendah menggunakan persentase. Dengan demikian 27\% kelompok tinggi dan $27 \%$ kelompok rendah dianggap yang terbaik untuk memaksimalkan perbedaan antara dua kelompok (Miller, 2002, p.68). Dari perhitungan tersebut diperolehan jumlah sampel adalah $19.44, \approx 20$ siswa dengan kemampuan power lengan tertinggi dan 20 siswa power lengan terendah. Tahap selanjutnya secara acak sederhana (random simple) untuk menentukan metode latihan yang akan diberikan.

Dari 20 siswa yang memiliki power tinggi diperoleh 10 siswa power tinggi masuk ke dalam kelompok metode drill dan 10 siswa power tinggi masuk ke dalam kelompok metode bermain. Dari 20 siswa yang memiliki power rendah diperoleh 10 siswa power rendah masuk ke dalam kelompok metode drill dan 10 siswa power rendah dengan metode bermain. Total keseluruhan sampel dalam penelitian ini adalah 40 siswa putra.

Penelitian ini merupakan penelitian eksperimen yang menggunakan rancangan faktorial $2 \times 2$. Adapun variabelnya yaitu variabel bebas berupa metode latihan (drill dan bermain), variabel terikat berupa hasil tolak peluru, dan variabel atribut yaitu power otot lengan.

Data yang diambil adalah data power otot lengan menggunakan intrumen tes shot put test (Widiastuti, 2011, p.100-101), dan instrumen hasil tolak peluru menggunakan tes dengan teknik tolak peluru gaya meluncur (glide). Tes power lengan dengan shot put test digunakan untuk menentukan jumlah sampel kedalam kelompok perlakuan, sedangkan tes hasil tolak peluru dilakukan sebelum (pretest) dan sesudah perlakuan (posttest).

Validitas tes dilakukan dengan menggunakan test retest. Validitas tes power lengan diperoleh sebesar 0,894, reliabilitas power lengan sebesar 0,942 dan validitas tes hasil tolak peluru adalah 0,756 , reliabilitas hasil tolak peluru adalah 0,942 .

Analisis data dilakukan dengan teknik analisis dua jalur (ANAVA), menggunakan bantuan SPSS statistics 20. Untuk memenuhi asumsi dalam teknik anava, maka dilakukan uji prasyarat. Adapun langkah-langkah analisis setiap data sebagai berikut: (1) uji normalitas dilakukan menggunakan rumus Kolmogrov Smirnov dengan program SPSS Statistics 20. Data dikatakan berdistribusi normal apabila nilai $\mathrm{p}>0,05 ;(2)$ uji homogenitas dilakukan dengan menggunakan uji Levene statistic. Kriteria pengambilan keputusan adalah varians dikatakan homogen apabila nilai 
p>0,05; (3) jika data terbukti normal dan homogen, maka akan dilanjutkan analisis parametrik dengan uji anava.

\section{HASIL DAN PEMBAHASAN}

Hasil analisis deskripsi yang disampaikan terdiri dari nilai rata-rata (mean), standar deviasi (SD) dari data pretest dan posttest sesuai dengan masing-masing kelompok. Adapun deskripsi data hasil tes tolak peluru dapat dilihat pada tabel 2.

Tabel 2. Deskripsi Data Hasil Tes Tolak Peluru

\begin{tabular}{lllllc}
\hline Perlakuan & Tingkat power otot lengan & Statistik & Hasil awal & Hasil akhir & Peningkatan \\
\hline \multirow{4}{*}{ Metode Drill } & \multirow{2}{*}{ Tinggi } & Jumlah & 57,44 & 80.05 & 22,61 \\
& & Mean & 5,744 & 8,005 & 2,261 \\
& \multirow{3}{*}{ Rendah } & SD & 0,887 & 0,697 & 0,591 \\
& & Jumlah & 45,02 & 58,73 & 13,71 \\
& \multirow{3}{*}{ Tinggi } & Mean & 4,502 & 5,873 & 1,371 \\
& & SD & 0,806 & 1,075 & 0,538 \\
\multirow{4}{*}{ Metode Bermain } & & Jumlah & 61,78 & 74,17 & 12,39 \\
& \multirow{3}{*}{ Rendah } & Mean & 6,178 & 7,417 & 1,239 \\
& & SD & 0,838 & 0,967 & 0,257 \\
& & Jumlah & 39,54 & 51,87 & 12,33 \\
& & Mean & 3,954 & 5,187 & 1,233 \\
\hline
\end{tabular}

Berikut ditampilkan data hasi tes tolak peluru pada pretest dan posttest masing-masing kelompok berdasarkan rerata atau mean dalam bentuk histogram.

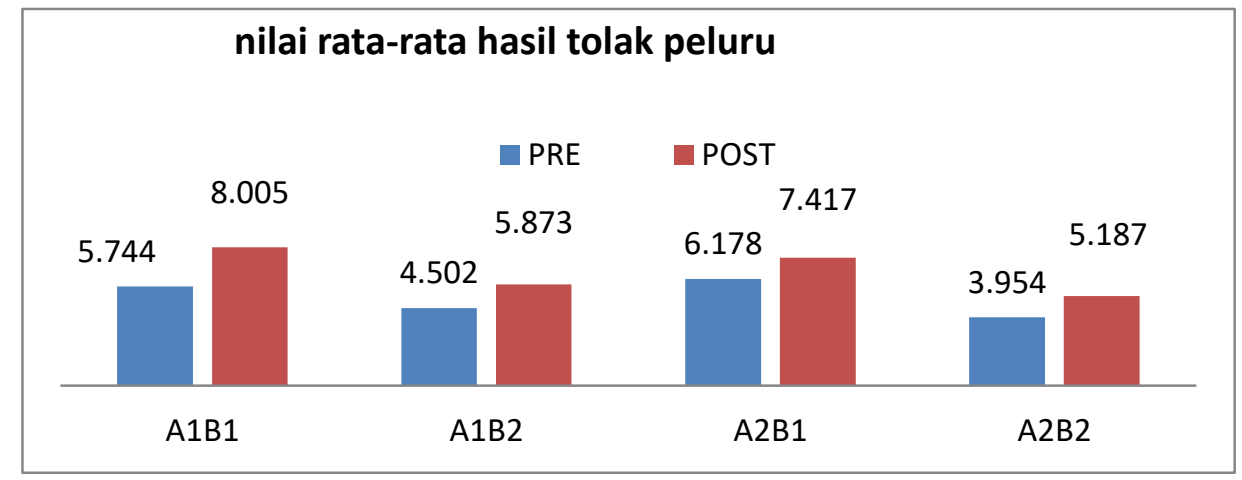

Gambar 1. Histogram rerata (mean) masing-masing kelompok.

Uji normalitas data pada penelitian ini menggunakan metode Kolmogorov Smirnov. Hasil uji normalitas data yang dilakukan pada tiap kelompok seperti pada tabel 3 di bawah ini.

Tabel 3. Uji Normalitas Posttest dan Pretest Hasil Tolak Peluru.

\begin{tabular}{lllrc}
\hline Kelompok Perlakuan & & N & Nilai Sig & Kesimpulan \\
\hline Drill Power Tinggi (KP 1) & Pretest & \multirow{2}{*}{10} & 0,946 & Normal \\
& Posttest & & 0,977 & Normal \\
Drill Power Rendah (KP 2) & Pretest & \multirow{2}{*}{10} & 0,609 & Normal \\
& Posttest & & 0,990 & Normal \\
Bermain Power Tinggi (KP 3) & Pretest & \multirow{2}{*}{10} & 0,926 & Normal \\
& Posttest & & 0,956 & Normal \\
Bermain Power Rendah(KP 4) & Pretest & \multirow{2}{*}{10} & 0,999 & Normal \\
& Posttest & & 0,838 & Normal \\
\hline
\end{tabular}

Tabel 4. Hasil uji homogenitas pretest dan postest

\begin{tabular}{llll}
\hline Test of Homogeneity of Variances & & & Kesimpulan \\
\hline \multirow{2}{*}{ Hasil awal } & Levene statistik & 1,372 & \multirow{2}{*}{ Homogen } \\
\multirow{2}{*}{ Hasil akhir } & Sig & 0,267 & \\
& Levene statistik & 0,751 & \multirow{2}{*}{ Hamogen } \\
\hline
\end{tabular}




\section{JORPRES (Jurnal Olahraga Prestasi), 15 (1), 2019 - 52}

Pasha Erik Juntara, Hari Amirullah Rachman

Hasil perhitungan homogenitas dengan levene, menunjukkan hasil pretest dengan signifikansi sebesar 0,267 >0,05 dan hasil posttest dengan signifikansi sebesar 0,529>0,05. Artinya hasil penelitian adalah seragam atau homogeny. Dengan demikian analisis selanjutnya dapat melalui statistik parametrik.

\section{Pengujian Hipotesis Penelitian Dengan Anava}

Tabel 5. Ringkasan Hasil Perhitungan Anava

\begin{tabular}{llll}
\hline \multicolumn{1}{c}{ Source } & \multicolumn{1}{c}{ Mean Square } & \multicolumn{1}{c}{ F } & \multicolumn{1}{c}{ Sig. } \\
\hline Corrected Model & 17,216 & 21,062 &, 000 \\
Intercept & 1753,241 & 2144,850 &, 000 \\
metode_latihan & 4,058 & 4,964 &, 032 \\
power_lengan & 47,568 & 58,192 &, 000 \\
metode_latihan * power_lengan &, 024 &, 029 &, 865 \\
Error &, 817 & &
\end{tabular}

\section{Pengujian Hipotesis 1}

Uji hipotesis yang berbunyi ada perbedaan pengaruh metode latihan drill dan metode bermain terhadap hasil tolak peluru diterima. Dengan kriteria keputusan sebagai berikut jika F hitung; $\mathrm{p}$, taraf signifikan 0,05. Dari tabel 5 diketahui harga signifikansi sebesar $0,032<0,05$ dengan $F$ hitung 4,964.

Dengan demikian hipotesis yang berbunyi ada perbedaan pengaruh metode latihan drill dan metode bermain terhadap hasil tolak peluru diterima. Artinya ada perbedaan pengaruh metode drill dan metode bermain terhadap hasil tolak peluru. Untuk mengetahui besar kecilnya pengaruh metode drill dan metode bermain terhadap hasil tolak peluru dapat dilihat pada tabel 6 .

Tabel 6. Mean Difference Metode Latihan

\section{Pairwise Comparisons}

Dependent Variable: hasil_tolak_peluru
(I) metode latihan
(J) metode latihan
Mean Difference (I-J)
drill
bermain
, $637^{*}$
$-, 637^{*}$

Hasil analisis pada Tabel 6 menunjukkan mean difference adalah 0,636. Berarti nilai rerata metode drill lebih besar dari nilai rerata metode bermain, jadi dapat disimpulkan bahwa metode drill memiliki pengaruh yang lebih besar dari pada metode bermain. Metode drill merupakan metode yang menggunakan system pengulangan, menekankan teknik yang benar dan mekanika gerakan dilakukan dengan step-by-step. Menurut Lucero (2013, p.38) drill work involves performing a rountine or exercice that emphasizes correct technique through repetition, exaggeration, contrast. Artinya drill berhubungan dengan melakukan rutinitas atau latihan yang ditekankan melalui pengulangan, teknik yang benar, dan berbeda. Metode drill terdiri dari pengulangan gerakan, hal ini sesuai dengan hukum latihan (law of exercise) yang dikemukakan oleh Throndike semakin sering tingkah laku diulang, dilatih dan dipraktikkan, maka asosiasi tersebut akan semakin kuat (Rahyubi, 2012, p.36). Menurut Kluge, et. al (2011, p.105) Traditional approaches: "Practice makes perfect.

Kelebihan metode drill adalah drill dan praktik telah sangat efektif sebagai metode untuk melatih individu untuk mendiagnosis bagian kesalahan yang dipraktikkan (Burkolter, et.al, 2010, p.978). Pada saat proses mendiagnosis suatu kesalahan dalam latihan terjadi sebuah proses yang disebut umpan balik. Menurut McMorris \& Hale (2006, p.133) feedback adalah istilah yang digunakan untuk menggambarkan semua informasi yang dihasilkan dari suatu tindakan atau respon. Kelebihan metode drill secara garis besar adalah (1) Memfasilitasi siswa belajar melalui latihan dari tugas untuk mencapai tingkat yang diingikan yaitu kemahiran. (2) Drill diberikan step-by step sehingga siswa dapat belajar teknik dengan baik, serta kesalahan dapat diagnosis dan dilakukan perbaikan. (3) Drill dilakukan melalui pengulangan latihan sehingga terjadi otomatisasi gerakan. (4) Dapat meningkatkan mental bagi siswa pada waktu melakukan tolak peluru.

Adapun kelemahan metode drill adalah sebagai berikut; (1) Kurang efisen dari segi waktu terutama bagi atlet memiliki kemampuan koordinasi gerak yang baik. (2) Pengulangan gerakan yang terus menerus dapat menimbulkan kebosanan dan membuat daya fikir tidak berkembang. 


\section{JORPRES (Jurnal Olahraga Prestasi), 15 (1), 2019 - 53}

Pasha Erik Juntara, Hari Amirullah Rachman

Metode latihan dengan bermain berpengaruh terhadap hasil tolak peluru karena, metode bermain merupakan metode latihan dengan menggunakan permainan yang mengarah pada aspek yang diperlukan dalam tolak peluru. Tolak peluru yang dilakukan dengan metode bermain terdiri dari gerakan-gerakan yang sesuai dengan aspek fisik dan teknik. Aspek fisik antara lain adalah power. Power merupakan hasil gabungan kekuatan dan kecepatan. Untuk itu aktivitas bermain yang digunakan berupa aktivitas yang mengandung unsur kekuatan dan kecepatan. Selanjutnya aktivitas bermain yang mengarah ke teknik merupakan serangkaian aktivitas bermain yang mengandung unsur teknik tolak peluru. Dalam tolak peluru terdapat beberapa fase yaitu persiapan, meluncur, power posisi, dan pelepasan peluru.

Metode bermain memiliki kelebihan dan kekurangan. Kelebihan metode bermain adalah: (1) Unsur dari bermain adalah pengulangan, sehingga dapat melatih keterampilan. Hal ini sesuai dengan Semiawan $(2009$, p.20) pada permulaan setiap pengalaman bermain memiliki unsur resiko, unsur lain dari bermain adalah pengulangan, dengan pengulangan anak-anak memiliki kesempatan mengkonsolidasikan keterampilan yang harus terwujud dalam berbagai permainan dengan berbagai nuansa yang berbeda. (2) Latihan yang dilakukan dengan bermain mengandung unsur bersaing atau kompetisi sehingga dapat meningkatkan daya saing dan rasa percaya diri serta kerjasama. Hal ini senada dengan Saputra (2001, p.9) bermain yang menyenangkan dan menantang serta terdapat unsurunsur yang terkandung didalamnya seperti berkompetisi. (3) Terdapat rintangan-rintangan yang dikemas dalam peraturan yang mengatur suatu latihan sehingga dapat melatih daya pikir. (4) Terdapat target atau sasaran sehingga dapat meningkatkan kekuatan menolak. (5) Bermain memiliki unsur resiko berupa menang dan kalah sehingga siswa bersungguh-sungguh melakukan latihan. (6) Latihan dengan cara bermain dapat meningkatkan daya tarik siswa, sehingga terlepas dari kondisi stress dan melakukan gerakan dengan gembira tidak tertekan. Hal ini senada dengan pendapat Meier (2004, p.206) permainan belajar jika dimanfaatkan secara bijaksana dapat: menyingkirkan keseriusan yang menghambat, menghilangkan stress dalam lingkungan belajar, mengajak individu terlibat lebih, meningkatkan proses belajar.

Kelemahan metode bermain adalah: (1) Bila sarana dan prasarana kurang memadai proses latihan menjadi tidak efektif. (2) Kurang efisien terutama bagi siswa yang memiliki power lengan rendah. (3) Rawan terjadi pelanggaran peraturan atau kecurangan dalam bermain. (4) Perlu perkenaan beban latihan kepada siswa, sehingga efek latihan dapat merata. (5) Ada beberapa aktivitas latihan yang memiliki sasaran sehingga siswa tidak leluasa untuk melakukan tolakkan.

Berdasarkan pembahasan tersebut dapat disimpulkan bahwa kedua metode latihan yaitu metode drill dan metode bermain berpengaruh terhadap hasil tolak peluru. Metode drill dan metode bermain masing-masing mempunyai kekurangan dan kelebihan. Metode drill memiliki pengaruh yang lebih besar terhadap hasil tolak peluru daripada siswa yang mendapat metode bermain. Pada saat latihan tidak menutup kemungkinan untuk menggunakan metode bermain. Artinya penerapan beberapa metode dalam latihan sangat diperlukan, sehingga latihan memiliki variasi dan tidak monoton serta membosankan.

\section{Pengujian Hipotesis 2}

Hipotesis kedua yang berbunyi ada perbedaan pengaruh power lengan tinggi dan power lengan rendah terhadap hasil tolak peluru. Dengan kriteria keputusan sebagai berikut jika F hitung; $\mathrm{p}$, taraf signifikan 0,05. Dari tabel 5 diketahui harga signifikansi sebesar $0,000<0,05$ dengan $\mathrm{F}$ hitung 58,192 . Dengan demikian hipotesis yang berbunyi ada perbedaan pengaruh power lengan tinggi dan power lengan rendah terhadap hasil tolak peluru diterima. Artinya ada perbedaan pengaruh power lengan tinggi dan power lengan rendah terhadap hasil tolak peluru. Untuk mengetahui besar kecilnya pengaruh power tinggi dan power rendah terhadap hasil tolak peluru dapat dilihat pada Tabel 7.

Tabel 7. Mean Difference Power Lengan

Pairwise Comparisons

Dependent Variable: hasil_tolak_peluru
(I) Power lengan
(J) Power lengan
Mean Difference (I-J) 


\section{JORPRES (Jurnal Olahraga Prestasi), 15 (1), 2019 - 54}

Pasha Erik Juntara, Hari Amirullah Rachman

Hasil analisis pada table 7 menunjukkan mean difference adalah 2,181. Berarti nilai rerata power lengan tinggi lebih besar dari nilai rerata power lengan rendah, jadi dapat disimpulkan bahwa power lengan tinggi memiliki pengaruh yang lebih besar dari pada power legan rendah.

Power (kekuatan explosive) yaitu kemampuan otot atau sekolompok otot untuk mengatasi beban dengan gerakan yang cepat, misalnya melompat, melempar dan memukul (Irianto, 2002, p.67). Pada tolak peluru power merupakan salah satu faktor penentu terhadap hasil tolakkan peluru. Parameter prestasi dalam tolak peluru adalah kecepatan saat melepaskan peluru (Purnomo, 2007, p.116). Gerakan percepatan terhadap beban relatif dari berat peluru dicapai oleh daya kekuatan pelurusan otot-otot tungkai, torso dan lengan.

Gerakan ini membutuhkan kekuatan terutama kekuatan maksimal, power dan kekuatan saat menolak serta kecepatan gerak yang harus dikoordinasi menjadi suatu gerakan yang dinamis. Shot put is dynamics event demanding high power production (Tarzis et.al, 2003, p.10). Tolak peluru adalah even dinamis yang memerlukan power tinggi. Power otot ditentukan oleh kekuatan otot, kecepatan gerakan dan aktifasi neuromuskuler (Kyriazis, et.al, 2009, p.1).

Setiap individu memiliki kemampuan yang berbeda-beda. Hal ini disebabkan setiap atlet memiliki potensi yang berbeda-beda dan karakter unik, setiap latihan menimbulkan respon yang berbeda (Irianto, et. al. 2009, p.8). Hal ini sesuai dengan prinsip individual menurt Thumm (2009, p.12) athletes are not identical. To respond to personal requirements and ensure constant improvement, separate training schedules shall be designed for each individual athlete considering their respective stage of progress. Artinya atlet tidak identik untuk menanggapi kebutuhan pribadi dan memastikan perbaikan terus-menerus, jadwal latihan yang terpisah harus dirancang untuk setiap individu mempertimbangkan tahap masing-masing kemajuan atlet. Perbedaan ini juga disebabkan oleh beberapa faktor yaitu keturunan, kematangan, gizi, waktu istirahat dan tidur, kebugaran, lingkungan, sakit cidera dan motivasi (Sukadiyanto, 2010, p.21).

Penyebab lain terjadinya perbedaan kemampuan power otot lengan dengan adanya partisipasi siswa pada cabang olahraga lain yang ada diekstrakurikuler. Siswa yang terlibat dan tidak terlibat dalam kegiatan ekstrakurikuler cabang olahraga lainnya baik secara langsung maupun tidak akan mempengaruhi kemampuan power siswa Siswa yang terlatih cenderung akan memiliki power otot lengan tinggi dan sebaliknya siswa yang tidak terlatih akan cenderung memiliki power yang rendah. Tinggi dan rendahnya power yang dimiliki seseorang merupakan salah satu faktor penentu dalam keterampilan olahraga.

Berdasarkan pemaparan tersebut dapat disimpulkan bahwa tinggi dan rendahnya power lengan yang dimiliki seseorang merupakan faktor penentu dalam keterampilan olahraga termasuk tolak peluru. Power otot lengan memiliki hubungan yang erat dalam menunjang kemampuan siswa untuk menghasilkan tolak peluru yang jauh. Meskipun power lengan memberikan pengaruh pada hasil tolak peluru, kinerja atau hasil tolak peluru juga ditentukan oleh power ekstremitas atas dan power ekstremitas bawah.

\section{Pengujian Hipotesis 3}

Hipotesis ketiga yang berbunyi ada interaksi antara metode latihan dan power otot lengan terhadap hasil tolak peluru ditolak. Hasil analisis menggunakan anava menunjukkan bahwa tidak ada interaksi antara metode latihan dan power lengan terhadap hasil tolak peluru. Hal ini terbukti dengan signifikansi sebesar $0,865>0,05$.

Berdasarkan hasil ini berarti pengungkapan kajian teori dan hipotesis yang telah diungkapan ternyata tidak sesuai dengan penelitian. Dengan tidak ada interaksi dalam penelitian ini berarti bagi siswa atau atlet pemula dengan power lengan tinggi maupun rendah dan diberikan kedua metode latihan tersebut dapat mencapai peningkatan hasil tolak peluru yang relatif sama.

Kelompok yang memiliki power lengan tinggi menunjukan pengaruh yang lebih baik terhadap hasil tolak peluru. Hal ini terjadi karena Power lengan merupakan kemampuan lengan dalam melakukan tolakan dengan kekuatan dan kecepatan. Pada tolak peluru kekuatan dan kecepatan merupakan salah satu faktor pendukung terhadap hasil tolak peluru. Menurut Purnomo (2007, p.116) parameter prestasi dalam tolak peluru salah satunya adalah kecepatan dalam melepas peluru dan kekuatan pelurusan otot lengan. Hal ini menunjukkan bahwa hasil tolak peluru berkaitan erat dengan kemampuan fisik dan karaktersitik subjek yang dilatih. 
Kelompok yang memiliki power lengan tinggi dari kedua metode latihan dengan drill dan metode latihan dengan bermain dan kelompok yang memiliki power lengan rendah dari kedua metode latihan drill dan metode latihan bermain, tidak menunjukkan perbedaan pengaruh yang signifikan. Artinya siswa yang memiliki power lengan tinggi akan lebih mudah melakukan tolak peluru, berlaku juga dengan siswa power lengan rendah yang dilatih dengan metode drill dan metode bermain, karena hasil akhir yang dicapai dari keempat kelompok tersebut tidak terlalu jauh berbeda.

Dapat disimpulkan bahwa metode drill, metode bermain dan power lengan tidak berpengaruh secara signifikan. Ini terjadi karena hasil akhir kelompok metode drill dengan power lengan tinggi dan hasil akhir metode bermain dengan power tinggi memiliki hasil akhir yang hampir sama. Hal yang sama terjadi pada hasil akhir kelompok metode drill dengan power lengan rendah dan kelompok metode bermain dengan power rendah memiliki hasil yang hampir sama.

Kelompok yang memiliki power lengan tinggi maupun kelompok yang memiliki power lengan rendah, ketika mendapat perlakuan sama-sama mengalami peningkatan baik dilatih dengan metode drill maupun dilatih dengan metode bermain. Metode drill lebih baik dibandingkan dengan metode bermain, namun metode bermain juga dapat meningkatkan hasil tolak peluru.

Dengan demikian dapat disimpulkan bahwa baik siswa yang memiliki power lengan tinggi dan power lengan rendah dalam tolak peluru sama-sama dapat dilatih baik menggunakan metode latihan drill maupun metode latihan bermain. Hal ini terjadi karena untuk memperoleh hasil yang baik dalam tolak peluru, selain memerlukan kondisi fisik juga harus didukung dengan latihan yang dilakukan secara berulang, bertahap, suasana yang kompetitif serta menyenangkan. Ini berarti bahwa kesuskesan suatu latihan tolak peluru ditentukan dengan penggunaan metode latihan yang tepat.

\section{SIMPULAN}

Berdasarkan hasil penelitian dan hasil analisis data yang telah dilakukan, dapat diperoleh kesimpulan sebagai berikut: Ada perbedaan pengaruh antara metode drill dan bermain terhadap hasil tolak peluru, metode drill memiliki pengaruh yang lebih besar dari metode bermain. Ada perbedaan pengaruh antara siswa yang memiliki power lengan tinggi dengan siswa yang memiliki power lengan rendah terhadap hasil tolak peluru, power lengan tinggi memiliki pengaruh yang lebih besar dari power lengan rendah. Tidak ada interaksi antara metode latihan dan power lengan terhadap hasil tolak peluru.

\section{DAFTAR PUSTAKA}

Anonim. (2006). Dictionary of sport \& exercise science. London: A \& C Black Publishers.

Bompa, T.O. (2000). Total training for young champions. Champaign: Human Kinetics.

Bompa, T.O \& Haff, G.G (2009). Periodezation: theory and methodology of training, $\left(5^{\text {th }} e d\right)$. Champaign: Human Kinetics.

Burkolter. D, et.al. (9 Maret 2010). Comparative study of three training methods for enhancing process control performance: Emphasis shift training, situation awareness training, and drill and practice. (versi elektronik). Journal: Computers in Human Behavior. Vol. 26. No. 5. Hal. 976986. Diambil pada tanggal 12 juli 2013, dari http://www.researchgate.net/publication/.pdf.

Derse, et.al. (2008). Track and field coaching manual life ready through sport. Los Angeles: La84 foundation.

Gordon, D. (2009). Coaching science. Cornwall: Learning Matters Ltd.

Hardini, I \& Puspitasari, D. (2012). Strategi pembelajaran terpadu. Yogyakarta: Familia.

Irianto, D.P. (2002). Dasar kepelatihan. Yogyakarta: FIK Universitas Negeri Yogyakarta.

Irianto, D.P., et.al. (2009). Materi latihan kondisi fisik dasar. Jakarta: ASDEP Pengembangan Tenaga dan Pembinaan Keolahragaan.

Kluge, A., et.al. (2011) The interaction of drill and practice and error training with individu differences. Journal: Cognition, Technology \& Work. Vol. 13. No 2. Hal. 103-120. diambil pada tanggal 5 September 2013, dari http://libgen.org./Volume 13/issue 2/doi. pdf. 
Komi, P.V. (Ed). (2003). Strength and power in sport. (2 $2^{\text {th }}$ ed., vol 3). Oxfort: International Olympic Committee Blackwell Science.

Kyriazis, T.A., et.al. (2009). Muscular power, neuromuscular activation, and performance in shot put athletes at preseason and at competition period. Journal of Strength and Conditioning Research. 23.6: 1773-9. Diambil 9 Juli 2013,dari http://search.proquest.com/docviewaccountid.pdf.

Lucero. B. (2013). 100 more swimming drills. Maidenhead: Meyer \& Meyer Sport.

Majid, A. (2013). Strategi pembelajaran. Bandung: PT Remaja Rosdakarya.

McMorris,T \& Hale, T. (2006) Coaching science theory into practice. West Sussex: University of Chichester.

Meier, D. (2004). The accelerated learning Hanbook (panduan kreatif dan efektif merancang program pendidikan dan pelatihan (Penerjemah Rahmani Astuti). Bandung: PT Mizan Pustaka.

Miller, D.K. (2002). Measurement by the physical educator why and how. New York: Mcgraw-Hill Companies.

Prayadi H.Y \& Rachman, H.A. (2013). Pengaruh metode latiha dan power lengan terhadap kemampuan bulu tangkis. Jurnal Keolahragaan. Vol I. No I. Hal: 63-71. Yogyakarta: Program Studi Ilmu Keolahragaan Program Pascasarjana Universitas Negeri Yogyakarta.

Purnomo, E. (2007). Pedoman mengajar dasar gerak atletik. Yogyakarta: Universitas Negeri Yogyakarta.

Purnomo, E \& Dapan. (2011). Dasar-dasar gerak atletik. Yogyakarta: Alfamedia.

Qodratillah, M.T, dkk, (2008). Kamus besar bahasa Indonesia pusat bahasa departemen pendidikan nasional, $\left(4^{\text {th }} e d\right)$.: Jakarta: PT Gramedia Pustaka Utama.

Rahyubi, H. (2012). Teori-teori belajar dan aplikasi pembelajaran motorik deskripsi dan tinjauan kritis. Bandung: Nusa Media.

Roestiyah, N.K. (2001). Strategi belajar mengajar. Jakarta: Rineka Cipta.

Sanjaya, W. (2009). Strategi pembelajaran berorientasi standar proses pendidikan. Jakarta: Kencana Prenada Media Group.

Saputra. Y.M. (2001). Pembelajaran atletik di sekolah dasar sebuah pendekatan pembinaan gerak dasar melalui permainan. Jakarta: Depdiknas.

Semiawan, C. R. (2008). Belajar dan pembelajaran prasekolah dan sekolah dasar. Cetakan ke-III dengan perbaikan. Jakarta: PT Indeks.

Sujiono, Y.N \& Sujiono, B. (2010). Bermain kreatif berbasis kecerdasan jamak. Jakarta: PT Indeks.

Sukadiyanto. (2010). Pengantar teori dan metodologi melatih fisik. Yogyakarta: FIK Universitas Negeri Yogyakarta.

Tedjasaputra, M.S. (2001). Bermain, main dan permainan. Jakarta: PT Grasindo.

Terzis.G, et al. (September 2003). Relationship between shot put performance and triceps brachii fiber type compesition and power production. European journal of applied physiology. Vol. 90. Hal. 10-15. Diakses tanggal 26 juni 2014. Dari http://link.springer.com/article/10.1007/s00421-0030847.pdf.

Thumm, H.P. (2009). Atletics I primary and lower secondary scholls the track and field book for. Tanzania. Dar Es Salaam: DOSB Germany.

Widiastuti. (2011). Tes dan pengukuran olahraga. Jakarta: PT Bumi Timur Jaya. 